\title{
Geometrical problem
}

\section{Mr. J. Robotham}

To cite this article: Mr. J. Robotham (1828) Geometrical problem, Philosophical Magazine Series 2, 3:15, 234-234, DOI: 10.1080/14786442808674630

To link to this article: http://dx.doi.org/10.1080/14786442808674630

曲 Published online: 10 Jul 2009.

Submit your article to this journal ש

III Article views: 4

Q View related articles ¿ 
IODINE IN CADMIUM.

Iodine is found in the great zinc foundry at Königshute in Upper Silesia, in the cadmium which accompanies the zinc ores.-Ibid.

ANALYSIS OF THE GREEN IRON ORE AND ARSENIATE OF LEAD.

According to Dr. Karsten, a variety of this ore from the Hollester mines near Siegen, in Rhein Prussia, consists of

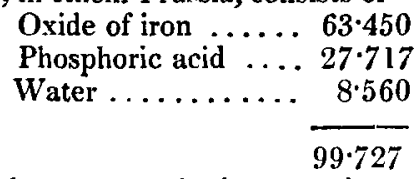

And according to the same authority, a variety of arseniate of lead from Herrhausen near Siegen, in Rhein Prussia, consists of

Oxide of lead ..... 69.97

Muriatic acid ...... 0.81

Arsenic acid $\ldots \ldots .29 \cdot 22$

$$
100 \cdot 00
$$

The results of this analysis are not accordant with those obtained by Dr. Wohler.-Poggendorff's Annalen, vol. iv. p. 161.

GEOMETRICAL PROBLEM. BY MR. J. ROBOTHAM.

Required, a square equal in area to the space comprised between the arcs $[A B, D C$, and $E F, D C$, $]$ of two concentric circles, and two parallel right lines, tangents to the interior circle. 'The area of the exterior circle being double that of the interior.

Let ABFE, and $d \mathrm{C} v \mathrm{D}$ be the two concentric circles. Bisect the quadrant $a$ of by the line $o B$. Then by the nature of the problem, the area $a \mathrm{~B} d e=d e 0=e o \mathrm{C}$. To each of these equals add the area $e B C$, then will the area of the space $a \mathrm{BC} d=$ the area of the triangle $o \mathrm{BC}$. And since

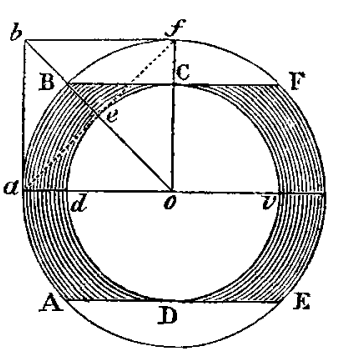
$0 a=o \mathrm{~B}$, the square, described on $o a$, viz. $a$ of $b=4$ times the area of the triangle $o \mathrm{BC}=$ the space $\mathrm{AB}, \mathrm{DC}$, and $\mathrm{EF}, \mathrm{DC}$. Which may be seen by drawingthe diagonal $a f$.

\section{SCIENTIFIC BOOKS. \\ Just Published.}

The 19th Number of Leybourn's Mathematical Repository; containing twenty mathematical questions, and their answers, selected from an extensive correspondence.-Horæ Arithmeticæ, by $\mathrm{Mr}$. Horner.-On Porisms, by Mr. Galloway,-On Central Forces, by the Rev, Mr. Bromhead.-On Equations, by the Rev. Mr. Hawkes. 